\title{
Gaseous health hazards in livestock confinement buildings
}

\author{
JUHANI KANGAS, KYÖSTI LOUHELAINEN and KAJ HUSMAN \\ Kuopio Regional Institute of Occupational Health, P.O. Box 93 \\ SF-70701 KUOPIO (Finland)
}

\begin{abstract}
Gas concentrations were measured on 16 farms (eight cattle farms, five piggeries, three poultry yards) mainly during wintertime. The gases were ammonia, carbon dioxide, methane, hydrogen sulfide, methyl mercaptan and other sulfides.

The mean concentrations of ammonia varied between $8-43 \mathrm{~cm}^{3} / \mathrm{m}^{3}$ in the air of livestock building. In the poultry yards the mean concentration of ammonia was highest; it was lower in piggeries and especially in cow houses. Carbon dioxide concentrations were $500-3500$ $\mathrm{cm}^{3} / \mathrm{m}^{3}$ in cowhouses, $1000-4000 \mathrm{~cm}^{3} / \mathrm{m}^{3}$ in hoghouses and $600-4000 \mathrm{~cm}^{3} / \mathrm{m}^{3}$ in poultry yards. Very low concentrations of methane and sulfur compounds were found in the livestock confinement buildings.

It is obvious that in normal working situations only ammonia of the measured gases exceeds the threshold limit value $\left(25 \mathrm{~cm}^{3} / \mathrm{m}^{3}\right)$. High ammonia concentrations can be expected in the floor type poultry confinement buildings especially when manure is left on the floor for several months. In such cases effective mechanical ventilation is the only way to keep the ammonia level acceptable.
\end{abstract}

Index words: farmers' gas exposure, ammonia, gases in livestock confinement buildings.

\section{Introduction}

Ammonia and hydrogen sulfide have been suspected to be an occupational health hazard for farm workers in livestock confinement buildings. These gases have been identified among the main components of malodorous gases from swine and poultry manure (SPOElSTRA 1980). There is, however, little information on occupational hygiene measure- ments of gas concentrations in different livestock buildings.

Ammonia, hydrogen sulfide, carbon dioxide and carbon monoxide were measured in swine producing farms by Donham and others (Donham \& Popendorf 1985). They found that ammonia most commonly exceeded the TLV (threshold limit value). According to their measurements other gases do not present an acute health hazard in normal situations. 
In the work of Batel (BATEL 1975), ammonia was found to reach higher concentrations in piggeries than in cow houses. Ammonia concentrations were $1-30 \mathrm{~cm}^{3} / \mathrm{m}^{3}$ in normal barn farms and $0-12 \mathrm{~cm}^{3} / \mathrm{m}^{3}$ in loose barn farms in Finland and the mean concentrations of different farms were $4-9 \mathrm{~cm}^{3} / \mathrm{m}^{3}$ and $1-9 \mathrm{~cm}^{3} / \mathrm{m}^{3}$ respectively (ANON 1975, KARHUNEN et al. 1979).

Jones et al. found ammonia levels of about $25 \mathrm{~cm}^{3} / \mathrm{m}^{3}$ in active work areas of poultry confinement buildings, but the levels could be much higher in areas with poor ventilation (JonEs et al. 1984).

In a turkey house ammonia was found to be between $40-50 \mathrm{~cm}^{3} / \mathrm{m}^{3}$, when the ventilation functions properly (AsCHBACHER 1973). In a normal work situation, the concentration of hydrogen sulfide is low, but may rapidly reach toxic levels if manure is agitated (DoNham et al. 1977, Donham et al. 1982, OsBorn \& CRAPO 1981) or the ventilation is off (Aschbacher 1973).

The objective of this study was to measure concentrations of ammonia, methane, carbon dioxide and sulfur compounds in Finnish livestock confinement buildings.

\section{Materials and methods}

Concentrations of gases were measured on 16 farms (8 dairy cattle houses, 5 piggeries and 3 poultry yards) mainly during wintertime. In one piggery and in three poultry yards ammonia was measured also during summer. Three of the piggeries had fattening pigs and two had both fattening pigs and sows. Two of the poultry houses were coop type units and one was a floor poultry yard. Seven livestock confinement buildings had mechanical ventilation with an exhaust volume of 800 to 8500 $\mathrm{m}^{3} / \mathrm{h}$ during measurements. In farms with natural ventilation, the exhaust air volume varied from 900 to $2300 \mathrm{~m}^{3} / \mathrm{h}$ during measurements.

The outdoor temperature varied during measurements from $+2{ }^{\circ} \mathrm{C}$ to $-20^{\circ} \mathrm{C}$ in winter, and from $+10^{\circ}$ to $+20^{\circ} \mathrm{C}$ in summer.
With the exception of carbon dioxide, the gases were measured mainly by stationary sampling method with sampling time from 0.5 h to 2 hours.

Ammonia samples were collected into impinger flasks containing $10 \mathrm{ml}$ of $0.1 \mathrm{M}$ sulfuric acid. Ammonium ion was detected with an ion selective electrode (Orion Research). The detection limit was $0.01 \mathrm{~cm}^{3} / \mathrm{m}^{3}$. Methane samples were collected in 41 laminated plastic bags and analyzed with a gas chromatograph (Hewlett Packard 5370A) equipped with a flame ionization detector. The column was packed with Carbowax $20 \mathrm{M}$, with pure nitrogen $(40 \mathrm{ml} / \mathrm{min})$ as the carrier gas and column temperature $60^{\circ} \mathrm{C}$. The detection limit for methane was $1.0 \mathrm{~cm}^{3} / \mathrm{m}^{3}$.

Hydrogen sulfide was collected into impinger flasks containing $30 \mathrm{ml}$ of $0.02 \mathrm{M}$ $\mathrm{CdSO}_{4}$ solution. Collected hydrogen sulfide was determined by methylene blue method (JACOBS, 1967). The detection limit for hydrogen sulfide was $0.01 \mathrm{~cm}^{3} / \mathrm{m}^{3}$.

On each farm, air samples were collected into a 41 plastic laminated bag in order to analyze the concentration of the principal sulfur compounds. The stability of samples in plastic laminated bags has been tested earlier (Kangas et al. 1986).

The samples in the bags were injected into a gas chromatograph (Analytical Instruments Development, Model 621-19) equipped with a flame photometric detector. A Teflon column was used packed with Chromosorb T $60 / 80$ coated with a mixture of polyphenylether and orthophosphoric acid. The oven temperature was $60^{\circ} \mathrm{C}$, and an optimum flame in the detector was achieved by purging with hydrogen $(55 \mathrm{l} / \mathrm{min})$ and air $(85 \mathrm{l} / \mathrm{min})$. Pure nitrogen served as the carried gas $(20 \mathrm{l} / \mathrm{min})$. This procedure yielded a good separation of the principal sulfur compounds with detection limits for hydrogen sulfide at $0.005 \mathrm{~cm}^{3} / \mathrm{m}^{3}$, for methyl mercaptan at $0.005 \mathrm{~cm}^{3} / \mathrm{m}^{3}$, for dimethyl sulfide at $0.03 \mathrm{~cm}^{3} / \mathrm{m}^{3}$ and for dimethyl disulfide at $0.05 \mathrm{~cm}^{3} / \mathrm{m}^{3}$.

Standards were prepared by permeation tube technique. The permeation rates of the 
standard gases are dependent on the ambient temperature. The permeation tube is placed in a thermostatic chamber and the permeated gas is diluted with nitrogen. By altering the carrier gas flow and temperature, the standard gas concentrations can be changed.

Carbon dioxide was determined by Draeger indicator tubes with Draeger hand pump (Drägerwerk AG Lübeck).

\section{Results}

With one exception, the ammonia concentrations in cow houses were below the TLV $\left(25 \mathrm{~cm}^{3} / \mathrm{m}^{3}\right)$. In piggeries and especially in poultry yards, the ammonia concentrations occasionally reached very high levels (Table 1). In one piggery and in three poultry yards ammonia levels were measured during both winter and summer. During summer the concentration of ammonia was three times higher than in wintertime. In poultry yards the ammonia level in ambient air was lower in summer than in winter.

The exposure of farmers to hydrogen sulfide on Finnish farms was found to be minimal normal working situations (Table 2). When manure was agitated, hydrogen sulfide was liberated and concentrations rising to 27 $\mathrm{cm}^{3} / \mathrm{m}^{3}$ were measured. Organic sulfur compounds (methyl mercaptan, dimethyl sulfide and dimethyl disulfide) in ambient air remained under the respective detection limit of the method used for analysis. Methane concentrations were highest on cattle farms, 35-290 $\mathrm{cm}^{3} / \mathrm{m}^{3}$ and lower in piggeries and poultry yards (Table 2). The concentration of carbon

Table 1. Ammonia concentrations in cow houses, piggeries and poultry yards, $\mathrm{cm}^{3} / \mathrm{m}^{3}$.

\begin{tabular}{lcccccc}
\hline & $\begin{array}{c}\text { cow } \\
\text { houses } \\
\text { winter }\end{array}$ & & \multicolumn{2}{c}{ piggeries } & & \multicolumn{2}{c}{ poultry yards } \\
\cline { 3 - 4 } \cline { 6 - 7 } & winter & summer & & winter & summer \\
& 7.8 & 17.8 & 35.8 & & 38.0 & 43.0 \\
mean & 6.6 & 11.2 & 16.0 & & 33.0 & 13.0 \\
$\mathrm{SD}$ & 0.2 & 4.7 & 16.4 & & 3.0 & 23.7 \\
min & 35.0 & 34.6 & 57.4 & & 138 & 67.2 \\
max & 50 & 42 & 4 & & 33 & 8 \\
$\mathrm{~N}$ & & & & & & \\
\hline
\end{tabular}

Table 2. Concentrations of hydrogen sulfide $\left(\mathrm{H}_{2} \mathrm{~S}\right)$, methane $\left(\mathrm{CH}_{4}\right)$ and carbon dioxide $\left(\mathrm{CO}_{2}\right)$ in cow houses, piggeries and poultry yards, $\mathrm{cm}^{3} / \mathrm{m}^{3}$.

\begin{tabular}{clccc}
\hline & & $\begin{array}{c}\text { cow } \\
\text { houses }\end{array}$ & piggeries & $\begin{array}{c}\text { poultry } \\
\text { yards }\end{array}$ \\
\hline & mean & 0.4 & 0.02 & 0.5 \\
$\mathrm{H}_{2} \mathrm{~S}$ & $\mathrm{SD}$ & 0.8 & 0.01 & 0.3 \\
& min & 0.01 & 0.01 & 0.3 \\
& max & 2.9 & 0.02 & 1.2 \\
& N & 11 & 10 & 5 \\
\hline & mean & 170 & 12 & 3 \\
& SD & 75 & 9 & - \\
$\mathrm{CH}_{4}$ & min & 35 & 5 & 3 \\
& max & 290 & 30 & 3 \\
& N & 8 & 6 & 3 \\
\hline & mean & 1520 & 2000 & 1900 \\
& SD & 850 & 920 & 910 \\
$\mathrm{CO}_{2}$ & min & 500 & 1000 & 600 \\
& max & 3500 & 4000 & 4000 \\
\hline
\end{tabular}

dioxide was similiar in different types of buildings and all results were below the TLV (5000 $\mathrm{cm}^{3} / \mathrm{m}^{3}$ ) (Table 2).

\section{Discussion}

Ammonia is formed through the hydrolysis of urea (Spoelstra 1980). Our results confirm earlier findings that ammonia is the most abundant gas in active areas of the livestock confinement buildings when compared to their threshold limit values. Especially in floor poultry yards high ammonia concentrations were measured during wintertime (maximum $138 \mathrm{~cm}^{3} / \mathrm{m}^{3}$ ). The reasons for these high ammonia levels were that manure is kept on the floor for several months during wintertime and there was no mechanical ventilation in these poultry yards, and the inlet ducts were tightly closed in order to maintain the air temperature comfortable for the hens.

Mechanical ventilation is needed to lower the ammonia concentration in poultry yards. This was noted during the summer when lower concentrations of ammonia were measured while doors and windows were kept open, even though the microbial hydrolysis of urea into ammonia is more active during the warm 
season. The influence of the outdoor temperature on the hydrolysis of urea was seen in the results of ammonia measurements in piggeries with mechanical ventilation. In wintertime the concentration of ammonia was lower than in summer. The difference in the ammonia concentrations between the floor and coop type poultry yards noted during wintertime was not noted in summer. This was probably due to the more effective natural ventilation in summer.

The high level of ammonia in poultry confinement buildings might be lowered by using some gas absorbing material such as a litter; for example peat could be effective for this purpose. The observed concentrations of ammonia in the poultry confinement buildings are so high that irritation of the eyes and mucous membranes are expected among the exposed farmers. According to our earlier measurements the piggeries and poultry yards were very dusty workplaces (LOUHELAINEN et al. in press). Ammonia may also adsorb to the dust particles, and by this way reach high local concentrations at the deposition areas of the farmers' lungs. This might partly explain the observed high prevalence of chronic bronchitis among Finnish farmers (TERHO et al. in press).

Methane reached highest concentrations in the dairy houses $\left(35-290 \mathrm{~cm}^{3} / \mathrm{m}^{3}\right)$. In piggeries and in poultry confinement buildings we measured clearly lower levels. In the nearly anaerobic conditions of cow rumen carbohydrate is fermented almost entire by into fatty acids and methane. This is most probably the main source of methane in cow houses (KAY 1983). In general, methane is the final product of microbial degradation of organic material. Methane in poultry yards and piggeries originates from this source (STEVEnS \& CORNFORTH
1974). However, methane concentrations are at such a low level that they do not provide an occupational health or safety hazard to the farmers in their active working areas.

Sulfur compounds are formed from the microbial degradation of sulfate-containing material in the manure. Sulfate-reducing bacteria produce mainly hydrogen sulfide but also other malodorous sulfur gases (mercaptans) can be found as a result of reduction of sulfur compounds in wastes (HATCHIKIAN 1976). We detected only hydrogen sulfide in the livestock confinement buildings and the concentration was low. We can conclude that during normal working situations (no agitation of the manure) there is no risk of excessive hydrogen sulfide exposure on the Finnish farms. The situation is quite different when the container of the liquid manure is pumped dry and the farmer has to work near the pit or the slurry tank (Donham et al. 1977, Donham et al. 1982, OsBorn \& CRAPO 1981).

Carbon dioxide is one of the main components of the breathing gases of the animals but it is also formed by microbial degradation of carbonaceous material (STEVENS \& CORNFORTH 1974). The level of carbon dioxide remained below TLV in all measurements. It has often been mentioned to be an indicator of indoor air quality. According to our measurements, there was no correlation between carbon dioxide and ammonia or methane. However, this would need further investigation focusing mainly on the correlation between the carbon dioxiode concentration and the ventilation in the livestock building. We believe that the concentration of carbon dioxide could be a rough indicator of the efficiency of ventilation in livestock confinement buildings.

\section{References}

ANON, 1975. Parsinavettatutkimus 1973-75. Vakolan tiedote 24/75, Vakola, Helsinki.

Aschbacher, P.W. 1973. Air pollution research needs: livestock production systems. J. Air. Poll. Cont. Ass. 23: 267-272.

BAtEl, W. 1975. Messungen zur Staub-, und Geruschs- 
belastung an Arbeitsplătzen in der Landvirtschaflichen Produktion und Wege zur Entlastung - Ertster Bericht. Grundlagen Landtechnik Bd 25: 135-157.

Donham, K.J. \& Popendorf, W.J. 1985. Ambient levels of selected gases inside swine confinement buildings. Am. Ind. Hyg. Assoc. J. 46: 658-661.

Donham, K.J., Knapp, L.W., Monson, B.S. \& GustafSoN, K. 1982. Acute toxic exposure to gases from liquid manure. J. Occup. Health. 24: 142-145.

Donham, K.J., Rubins, M., Thedel., T.D., Kannermeyer, J. 1977. Potential health hazards to agricultural workers in swine confinement buildings. J. Occup. Med. 19: 383-387.

Hatchikian, E.C., Chaigneau, M. and Le Gall J. 1976. Analysis of gas production by growing cultures of three species of sulfate-reducing bacteria. In: H.G. Schlegel, G. Gottschalk and N. Pfennig (Eds.), Microbial Production and Utilization of Gases. E. Goltze, K.G. Göttingen, 109-118.

JAcoBs, M.B. 1967. The analytical toxicology of industrial inorganic poisons pp. 545-548. Interscience Publishers John Wiley \& Sons, New York (Sydney) London.

Jones, W., Morring, K., Olenchock, S.A. Williams, T. \& HıCKEY, J. 1984. Environmental study of poultry confinement buildings. Am. Ind. Hyg. Assoc. J. 45: 760-766.

Kangas, J., Nevalainen, A., Manninen, A. and SavolaiNEN, H. 1986. Ammonia, hydrogen sulphide and methyl mercaptides in Finnish municipal sewage plants and pumping stations. The Sci Total Environ. 57: 49-55.

Karhunen, J., Pyykkönen, M., Mykkānen, U., NiemiNEN, L. and SAloniemi, H. Pihattotutkimus 1976-78. Vakolan tiedote 29/79. Vakola, Helsinki 1979.

KAY, R.N.B. Rumen function and physiology. The Vet Rec July 2, 1983, 6-9.

Louhelainen, K., Kangas, K., Husman, K. \& Terho, E.O.: Total concentrations of dust in the air during farm work: In: Terho E.O., Husman, K. \& Vohlonen, I. (eds.) Work - related respiratory diseases among Finnish farmers. Eur. J. Resp. Dis. Suppl. in press. Osborn, L.M., Crapo, R.O. 1981. Dung Lung: a report of toxic exposure to liquid manure. Ann. Inter. Med. 95: 312-314.

Spoelstra, S.F. 1980. Origin of objectionable odorous components in piggery wastes and the possibility of applying indicator components for studying odour development. Agric. Environ. 5: 241-260.

Stevens, R.J. and Cornforth, I.S. 1974. The effect of aeration and gases produced by slurry during storage. J. Sci Food Agric 25: 1249-1261.

Terho, E.O., Husman, K. \& Vohlonen, I.: Prevalence and incidence of chronic bronchitis and farmer's lung with respect to age, sex, atopy and smoking. In: Terho E.O., Husman K. \& Vohlonen, I. (Eds.) Work-related respiratory diseases among Finnish farmers. Eur. J. Resp. Dis. Suppl. In press.

Ms received March 2, 1987

\section{SELOSTUS}

\section{Kaasumaiset ilman epäpuhtaudet tuotantorakennuksissa}

\author{
Juhani Kangas, Kyösti Louhelainen, \\ Kaj Husman
}

Kuopion aluetyöterveyslaitos, PL 93, 70701 Kuopio

Tutkimuksessa mitattiin ilman kaasupitoisuuksia 16 maatilalla (kahdeksan navettaa, viisi sikalaa ja kolme kanalaa) paaăasiassa talviaikaan. Kaasut olivat ammoniakki, hiilidioksidi, metaani, rikkivety, metyylimerkaptaani ja sulfidit.

Työsuojeluhallituksen antamat 8 tunnin HTP-arvot (haitalliseksi tunnetut pitoisuudet) eri kaasuille ovat: ammoniakki $25 \mathrm{~cm}^{3} / \mathrm{m}^{3}$, rikkivety $10 \mathrm{~cm}^{3} / \mathrm{m}^{3}$, metyylimerkaptaani $0,5 \mathrm{~cm}^{3} / \mathrm{m}^{3}$ ja hiilidoksidi $5000 \mathrm{~cm}^{3} / \mathrm{m}^{3}$. Metaanille ja muille rikkiyhdisteille tăllaisia arvoja ei ole.
Keskimääräiset ammoniakkipitoisuudet olivat navetoissa $7,8 \mathrm{~cm}^{3} / \mathrm{m}^{3}$ (vaihtelu $0,2-35 \mathrm{~cm}^{3} / \mathrm{m}^{3}$ ), sikaloissa 17,8 $\mathrm{cm}^{3} / \mathrm{m}^{3}\left(4,7-34,6 \mathrm{~cm}^{3} / \mathrm{m}^{3}\right)$ ja kanaloissa $38,0 \mathrm{~cm}^{3} / \mathrm{m}^{3}$ $\left(3,0-138 \mathrm{~cm}^{3} / \mathrm{m}^{3}\right)$ talvella. Kesällä tehdyissă mittauksissa yhdessä sikalassa ammoniakkia oli keskimäärin 35,8 $\mathrm{cm}^{3} / \mathrm{m}^{3}\left(16,4-57,4 \mathrm{~cm}^{3} / \mathrm{m}^{3}\right)$ ja kolmessa kanalassa 43,0 $\mathrm{cm}^{3} / \mathrm{m}^{3}\left(23,7-67,2 \mathrm{~cm}^{3} / \mathrm{m}^{3}\right)$.

Rikkivetypitoisuudet olivat alhaiset kaikissa tuotantorakennuksissa normaalin työn aikana. Sekoitettaessa lietelantaa lantakourussa rikkivetypitoisuus nousi 27 
$\mathrm{cm}^{3} / \mathrm{m}^{3}$. Muiden rikkiyhdisteiden (metyylimerkaptaani, dimetyylisulfidi ja dimetyylidisulfidi) olivat alle analyysilaitteen määritysrajan (alle $0,05 \mathrm{~cm}^{3} / \mathrm{m}^{3}$ ). Metaanipitoisuudet olivat alhaiset ja niiden työhygieeninen merkitys vähäinen.

Hiilidioksidipitoisuudet olivat navetoissa $500-3500$ $\mathrm{cm}^{3} / \mathrm{m}^{3}$, sikaloissa $1000-4000 \mathrm{~cm}^{3} / \mathrm{m}^{3}$ ja kanaloissa $600-4000 \mathrm{~cm}^{3} / \mathrm{m}^{3}$.
Tutkimustulosten mukaan ammoniakki on mitatuista kaasuista haitallisin kotieläinrakennuksissa. Suurimmat pitoisuudet (maksimi $138 \mathrm{~cm}^{3} / \mathrm{m}^{3}$ ) mitattiin lattiakanaloissa talvella. Syinä korkeaan ammoniakkipitoisuuteen ovat $\mathrm{mm}$. lattialla oleva lanta ja vähäinen ilmanvaihtomäärä. Muiden kaasujen pitoisuudet olivat alle HTParvojen. 